\title{
Analisis Penerapan PSAK No.24 (Revisi 2013) tentang Imbalan Kerja pada PT. XYZ
}

\section{Analysis of PSAK No.24 (Revised 2013) Implementation about Employee Benefits of PT. XYZ}

\author{
Auliffi Ermian Challen \\ Accounting Study Program, Faculty of Economics and Business, YARSI University, Jakarta \\ Jalan Letjen. Suprapto, Cempaka Putih, Jakarta 10510 \\ Telepon (021) 4206674, 4206675, 4206676 \\ E-mail:auliffi.ermian@yarsi.ac.id
}

KEYWORDS post-employment benefits, actuarial gains/losses, post-employment benefits expenses, post-employment benefits liabilities

ABSTRACT The purpose of this study is to determine the difference between SFAS 24 revision 2013 and SFAS no 24 revised 2010, as well as the impact of the application of SFAS no 24 revision 2013 on the Company's Financial Statement of PT XYZ with the difference calculation by independent actuaries. The research was conducted by descriptive method through case study approach at PT XYZ with data collection method, and analysis of document obtained from company. The results of this study indicate that there is a difference between PSAK No. 24 revised 2010 and PSAK no 24 revision 2013. The difference is the acknowledgment of actuarial gains/losses, the components of the post-employment benefits expenses, and the components of the post-employment liabilities obligations (liabilities). Thus, the adoption of PSAK No. 24 revision 2013 , provides an impact on the need to reevaluate the post-employment benefits and post-employment benefits obligations (liabilities) benefits by an independent actuaries. This application leads to a restatement of the post-employment benefits fee and post-employment liability (liabilities) obligations. The balance of post-employment benefits expense decreased and post-employment liabilities liabilities increased significantly.

\section{PENDAHULUAN}

Pada tahun 2008, Ikatan Akuntan Indonesia (IAI) meresmikan program konvergensi International Financial Reporting Standards (IFRS), yaitu prinsip akuntansi yang berlaku umum di Indonesia (Indonesian GAAP) akan dikonvergensikan secara penuh dengan
IFRS pada tanggal 1 Januari 2012 (IAI). Konvergensi IFRS ini merupakan salah satu kesepakatan pemerintah Indonesia sebagai anggota forum G-20 yang bertujuan untuk Strengthening Financial Supervision and Regulation. IFRS merupakan standar pencatatan dan pelaporan akuntansi yang berlaku secara internasional yang dibuat oleh 
International Accounting Standar Boards (IASB) dengan tujuan untuk mengembangkan suatu standar akuntansi yang dapat dimengerti, diperbandingkan, dan diterima secara internasional (Paath \& Nangoi, 2015).

Telah lebih dari 100 negara mengadopsi IFRS. Regulator berharap bahwa penggunaan IFRS dapat meningkatkan komparabilitas laporan keuangan, meningkatkan transparansi perusahaan dan kualitas pelaporan keuangan sehingga menguntungkan investor (Cahyonowati dan Ratmono, 2012). Penelitian Alali dan Foote (2012) menunjukkan bahwa informasi akuntansi yang telah disusun berdasar IFRS lebih berkualitas dibandingkan informasi akuntansi yang disusun berdasar standar akuntansi sebelumnya.

Tahap adopsi di Indonesia telah dimulai sejak tahun 2008 dan tahap implementasi tahun 2012. Revisi Standar Akuntansi Keuangan (SAK) yang konvergensi ke IFRS oleh Dewan Standar Akuntansi Keuangan (DSAK) IAI akan terus berjalan mengikuti revisi yang dilakukan IASB. Pada 2015 ini pun mulai diterapkan SAK yang revisi 2013. Salah satunya adalah PSAK no 24 mengenai imbalan kerja. Latar belakang penerapan PSAK 24 tentang Imbalan Kerja adalah Undang-Undang Ketenagakerjaan (UUK) Nomor 13 Tahun 2003 mengatur secara umum mengenai tata cara pemberian imbalan-imbalan di perusahaan antaralain imbalan kerja dan imbalan pascakerja.

Pemberlakuan UUK ini dapat mengakibatkan perusahaan dibebani dengan jumlah pembayaran pesangon yang tinggi terutama perusahaan yang mempunyai jumlah karyawan ribuan orang. Oleh sebab itu, untuk mengantisipasi adanya kemungkinan gangguan aliran kas (cash flow) perusahaan akibat dari ketentuan dalam
UUK tersebut, maka PSAK No. 24 mengharuskan perusahaan untuk membukukan pencadangan atas kewajiban pembayaran pesangon/imbalan kerja dalam laporan keuangannya.

PSAK 24 revisi 2013 telah disahkan oleh Dewan Standar Akuntansi Keuangan pada 19 Desember 2013. PSAK baru ini merevisi PSAK 24 revisi 2010. Sejak tahun 1994 dengan nama PSAK 24 Akuntansi Biaya Manfaat Pensiun, PSAK ini telah mengalami beberapa kali perubahan dan revisi yaitu tahun 2006, 2010, dan terakhir 2013. Perubahan PSAK 24 dilakukan karena terjadi perubahan dan revisi atas IAS 19 Employee Benefit.

PSAK 24 ini telah diterbitkan sejak 2013 sedangkan penerapan PSAK 24 (Revisi 2013) berlaku efektif bagi perusahaan di Indonesia tanggal 1 Januari 2015. Akibat perubahan standar akuntansi ini, maka perusahaan memperlakukan perubahan kebijakan akuntansi dengan menggunakan pendekatan restrospektif sebagaimana telah ditentukan berdasarkan PSAK No. 25 tentang Laba atau Rugi bersih untuk periode berjalan, kesalahan mendasar, dan perubahan akuntansi. Penerapannya dilakukan secara retrospektif yakni tahun 2014 dan 2013. Sehingga dalam laporan auditor independen di tahun 2015 ini disajikan kembali laporan posisi keuangan untuk tahun 2014 dan 2013.

Menurut Sinaga (2014), ada beberapa alasan dilakukannya revisi atas PSAK 24 antara lain untuk melaporkan perubahan kewajiban imbalan pasti dan aset program didefinisikan dengan cara yang lebih dimengerti selain itu adanya beberapa opsi penyajian yang diizinkan dalam standar yang ada, membatasi komparabilitas.

Dalam PSAK 24 (2010) diberikan dua opsi untuk dalam pengakuan 
keuntungan dan kerugian aktuarial yakni dapat menggunakan koridor atau tanpa menggunakan koridor dengan diakui dalam pendapatan komprehensif lain (IAI, 2010). Dalam PSAK 24 (2013) pengakuan keuntungan dan kerugian aktuarial tidak boleh lagi menggunakan koridor sehingga hanya boleh diakui dalam pendapatan komprehensif lain. Perubahan ini tentunya akan memberikan kejelasan bagi perusahaan dalam menghitung estimasi liabilitas imbalan pasca kerja. Selain itu penerapan yang sudah seragam untuk semua perusahaan yang menerapkan IFRS tentunya menjadikan laporan keuangan perusahaan dapat diperbandingkan. Hal ini menjadi menarik untuk diteliti lebih lanjut bagaimana pengaruh dari penerapan PSAK 24 revisi 2013 terhadap penyajian kembali laporan posisi keuangan untuk tahun 2014 yang sebelumnya menerapkan PSAK 24 revisi 2010. Berdasarkan uraian di atas maka perumusan masalah dalam penelitian ini adalah 1) Apakah perbedaan antara PSAK 24 revisi 2013 dengan revisi $2010,2)$ Bagaimanakah perbedaan perhitungan aktuaris independen atas kewajiban imbalan pascakerja dan beban imbalan pascakerja tahun 2014 berdasarkan PSAK 24 revisi 2010 dan PSAK 24 revisi 2013? 3) Bagaimanakah dampak penerapan PSAK 24 revisi 2013 pada Laporan Keuangan Perusahaan PT $\mathrm{XYZ}$ ?

\section{METODOLOGI}

Jenis penelitian yang digunakan adalah penelitian deskriptif dengan mendatangi objek penelitian yaitu PT XYZ untuk memperoleh data-data dan informasi yang dibutuhkan. Penelitian juga dilakukan dengan studi literatur khususnya PSAK 24 untuk memahami teknik pemecahan masalah berdasarkan permasalahan yang ada didalam internal perusahaan dalam menghadapi perubahan PSAK terkini khususnya revisi terbaru PSAK 25 (2013) yang berlaku efektif 1 Januari 2015.

Analisis data dilakukan dengan mengumpulkan data-data kemudian mengolah data dan melakukan interpretasi hasil penelitian. Penelitian ini membatasi ruang lingkup PSAK 24 hanya terbatas pada program imbalan pasti. Pengakuan dan pengukuran berdasarkan PSAK 24 dalam program imbalan pasti, perusahaan wajib menyediakan imbalan yang dijanjikan kepada karyawan maupun mantan karyawan serta risiko investasi dan aktuaria menjadi tanggungan perusahaan (IAI, 2010). Risiko-risiko liabilitas imbalan kerja secara jangka panjang membuat perusahaaan harus memiliki strategi dan pengetahuan yang memadai dalam menghadapi risiko-risiko tanpa mengganggu kinerja perusahaan di masa mendatang. PT XYZ merupakan perusahaan yang bergerak di bidang tekstil mempunyai lebih dari 3000 karyawan. Untuk setiap tahunnya selalu melakukan pengakuan atas liabilitas imbalan pasca kerja bagi karyawannya.

Pada tahun 2014, estimasi liabilitas imbalan pasca kerja dihitung oleh aktuaris independen menggunakan metode koridor. Sejak penerapan PSAK 24 (2013) yang berlaku efektif 1 Januari 2015, aktuaris independen menerapkan aturan PSAK 24 tersebut sehingga pengakuan keuntungan dan kerugian aktuarial diakui langsung sebagai pendapatan komprehensif lainnya. Perubahan metode pengakuan keuntungan dan kerugian aktuarial ini tentunya memberikan perbedaan 
pengakuan atas beban imbalan pascakerja dan liabilitas imbalan pascakerja.

\section{ISI}

\section{Perbedaan PSAK 24 revisi 2010 dan PSAK 24 revisi 2013}

Pada Tabel 1 berikut ini penjelasan untuk perbedaan PSAK 24 revisi 2010 dan PSAK 24 revisi 2013 yang dibatasi pada imbalan pascakerja program imbalan pasti Perbedaan perhitungan aktuarias independen atas kewajiban imbalan pascakerja dan beban imbalan pasca kerja tahun 2013 berdasarkan PSAK 24 revisi 2010 dan PSAK 24 revisi 2013.

Data pekerja dan asumsi perhitungan aktuaris pada PT XYZ dituliskan dalam Tabel 2 DAN 3. Perbedaan Perhitungan aktuaris independen atas liabilitas (kewajiban) imbalan pascakerja dan beban imbalan pascakerja tahun 2013 berdasarkan PSAK 24 revisi 2010 dan PSAK 24 revisi 2013 dapat dilihat pada Tabel 4.

Tabel 1. Perbedaan PSAK 24 revisi 2010 dan PSAK 24 revisi 2013

\begin{tabular}{|c|c|c|}
\hline Karakteristik & PSAK 24 (2013) & PSAK 24 (2010) \\
\hline $\begin{array}{l}\text { Keuntungan } \\
\text { dan kerugian } \\
\text { actuarial }\end{array}$ & $\begin{array}{l}\text { Dihapus, Penangguhan pengakuan } \\
\text { keuntungan dan kerugian aktuaria tidak } \\
\text { diizinkan. Keuntungan dan kerugian } \\
\text { aktuarial langsung diakui dalam OCI } \\
\text { (Other Comprehensive Income). } \\
\text { Reklasifikasi jumlah yang diakui dalam } \\
\text { OCI ke laporan laba rugi tidak diizinkan. }\end{array}$ & $\begin{array}{l}\text { Entitas harus mengukur } \\
\text { atau kerugian aktuaria dari setiap } \\
\text { program imbalan pasti. } \\
\text { dan kerugian aktuarial dapat langsung } \\
\text { diakui dalam laba rugi atau } \\
\text { ditangguhkan melalui pendekatan } \\
\text { koridor. }\end{array}$ \\
\hline $\begin{array}{l}\text { Komponen } \\
\text { biaya imbalan } \\
\text { pasti }\end{array}$ & $\begin{array}{l}\text { Komponen biaya imbalan pasti: } \\
\text { (a) biaya jasa; } \\
\text { (b) bunga neto atas liabilitas (aset) } \\
\text { imbalan pasti neto; dan } \\
\text { c) pengukuran kembali liabilitas (aset) } \\
\text { imbalan pasti neto }\end{array}$ & Tidak diatur spesifik \\
\hline Beban pensiun & $\begin{array}{l}\text { Komponennya terdiri dari beban jasa kini, } \\
\text { jasa lalu, keuntungan dan kerugian } \\
\text { penyelesaian dan bunga neto atas liabilitas } \\
\text { (aset) imbalan pasti neto. }\end{array}$ & $\begin{array}{l}\text { Komponennya terdiri dari biaya jasa } \\
\text { kini, biaya jasa lalu, amortisasi } \\
\text { keuntungan atau kerugian aktuaria (jika } \\
\text { melebihi koridor), bunga dan hasil yang } \\
\text { diharapkan dari aset program, serta } \\
\text { dampak dari kurtailmen atau } \\
\text { penyelesaian program. }\end{array}$ \\
\hline $\begin{array}{l}\text { Penyajian } \\
\text { liabilitas } \\
\text { (aset) } \\
\text { imbalan pasti }\end{array}$ & $\begin{array}{l}\text { Liabilitas (aset) imbalan pasti men- } \\
\text { cerminkan jumlah defisit/surplus } \\
\text { program imbalan kerja jangka panjang }\end{array}$ & $\begin{array}{l}\text { Liabilitas (aset) imbalan pasti neto } \\
\text { tidak selalu mencerminkan jumlah } \\
\text { defisit/surplus program imbalan kerja } \\
\text { jangka panjang ("metode koridor") }\end{array}$ \\
\hline
\end{tabular}

Sumber: diolah dari berbagai sumber 
Tabel 2. Data Pekerja

\begin{tabular}{ll}
\hline Komponen & 2013 \\
\hline Jumlah pekerja (orang) & 4.310 \\
Rata-rata usia (tahun) & 33,09 \\
Jumlah upah sebulan (Rp) & 10.468 .327 .286 \\
\hline
\end{tabular}
Sumber: Perusahaan XYZ

Tabel 3. Asumsi Perhitungan

\begin{tabular}{ll}
\hline \multicolumn{1}{c}{ Keterangan } & 2013 \\
\hline Usia Pensiun & 55 \\
Tingkat kenaikan gaji & $8,0 \%$ \\
Tingkat Bunga & $9,0 \%$ \\
\hline
\end{tabular}

Sumber: Perusahaan XYZ

Tabel 4. Perhitungan Aktuaris (dalam Rupiah)

\section{U R A I A N}

PSAk Lama

PSAK Revisi

Perhitungan Keuntungan/Kerugian Aktuaria :

1. Nilai Kini Kewajiban pada awal periode

$65,038,746,085$

$65,038,746,085$

2. Dampak perubahan Kurtailmen dan Penyelesaian

3. Dampak perubahan asumsi aktuaria

$(15,807,302,231)$

$(15,807,302,231)$

4. Beban Jasa Kini :

$5,467,094,719$

$5,467,094,719$

- Jasa Kini Karyawan

- Jasa Kini Perusahaan

$5,467,094,719$

$5,467,094,719$

5. Beban Bunga

6. Pembayaran Imbalan Pasca Kerja periode berjalan

$5,853,487,148$

$5,853,487,148$

$28,449,960,866$

$28,449,960,866$

7. Total Beban $(1+2+3+4+5-6)$

$32,102,064,854$

$32,102,064,854$

8. Nilai Kini Kewajiban pada akhir periode

$64,340,268,839$

$64,340,268,839$

9. Keuntungan/(Kerugian) Aktuaria berjalan (7-8-3)

$(16,430,901,753)$

$(\mathbf{1 6 , 4 3 0 , 9 0 1 , 7 5 3 )}$

\section{Corridor Test :}

1. $10 \%$ dari Nilai Kini Kewajiban

$6,503,874,608$

2. $10 \%$ dari Nilai Wajar Aktiva

Corridor Test (lebih besar diantara 1 dan 2)

$6,503,874,608$

Akumulasi Keuntungan/(Kerugian) Aktuaria yang

belum diakui :

Akumulasi Keuntungan/(Kerugian) Aktuaria periode

1. lalu yang belum diakui

$(46,424,743,013)$ 
Keuntungan/(Kerugian) Aktuaria periode berjalan yang

2. belum diakui

Akumulasi Keuntungan / (Kerugian) Aktuaria yang

3. diakui sisa masa kerja

Akumulasi Keuntungan/(Kerugian) Aktuaria yang belum

diakui (1+2-3)

Pendapatan Komprehensif Lain (Par 99-102)

1. Pendapatan Komprehensif Lain awal periode

Keuntungan/(Kerugian) Aktuaria periode berjalan

2. (2.1.+2.2.)

2.1. Keuntungan/(Kerugian) Aktuaria terhadap

Kewajiban

2.2. Keuntungan/(Kerugian) Aktuaria terhadap Aktiva program

Asset Yang Tidak Diperkenankan Pada Akhir Periode

3. (Par 64)

4. Pendapatan Comprehensive Lain Periode Berjalan

Pendapatan Komprehensif Lain pada akhir periode

Rekonsiliasi Beban Imbalan Pasca-Kerja yang diakui di Laporan Laba/Rugi

1. Beban Jasa Kini :

- Jasa Kini Karyawan

- Jasa Kini Perusahaan

$5,467,094,719$

$5,467,094,719$

2. Beban Bunga

3. Amortisasi Biaya Jasa Lalu (Vested) yang diakui Amortisasi Biaya Jasa Lalu (Non Vested) yang belum

4. diakui Amortisasi Akumulasi (Keuntungan) / Kerugian

5. Aktuaria

Kelebihan Pembayaran Imbalan Pasca kerja dari yang

6. dicadangkan

7. Dampak perubahan Kurtailmen dan Penyelesaian

Beban Imbalan Pasca-Kerja yang diakui di Laporan

Laba/Rugi $(1+2+3+4+5+6+7)$

Rekonsiliasi Perubahan Aktiva/Kewajiban Yang diakui di Neraca

1. Nilai Kini Kewajiban pada akhir periode

2. Nilai Wajar Aktiva akhir periode (jika ada pendanaan)

3. Status Pendanaan (1-2)

4. Biaya Jasa Lalu (Non Vested) yang belum diakui Akumulasi Keuntungan / (Kerugian) Aktuaria yang

Kewajiban yang diakui di Neraca (3-4+5)

Rekonsiliasi Perubahan pada Aktiva/Kewajiban yang 
1. (Aktiva) Kewajiban pada awal periode Beban Imbalan Pasca-Kerja yang diakui periode

2. berjalan Pembayaran Imbalan Pasca Kerja selama periode

3. berjalan Kelebihan Pembayaran Imbalan Pasca kerja dari yang

4. dicadangkan

5. Iuran Dana Pensiun / Premi Asuransi
$18,614,003,072$

$31,281,016,069$

$28,449,960,866$
$18,614,003,072$

$11,320,581,867$

$28,449,960,866$

6. Pendapatan Komprehensif Lain Periode Berjalan

(Aktiva) Kewajiban pada tanggal Neraca (1+2-3-4-5) Sumber: Perusahaan XYZ

Berdasarkan data perhitungan aktuaris (Tabel 4) dapat dilihat bahwa dengan adanya revisi PSAK, keuntungan dan kerugian aktuarial tidak diperkenankan lagi. Keuntungan dan kerugian aktuarial langsung diakui dalam Pendapatan komprehensif lain (OCI-Other Comprehensive Income). Reklasifikasi jumlah yang diakui dalam pendapatan komprehensif lain (OCI) tidak diperkenankan ke laporan laba rugi. Komponen dari beban imbalan pasca kerja yang diakui dalam Laporan Laba Rugi pada PSAK lama adalah biaya jasa kini, biaya jasa lalu, amortisasi keuntungan atau kerugian aktuaria (jika melebihi koridor), bunga dan hasil yang diharapkan dari aset program, serta dampak dari kurtailmen atau penyelesaian program. Dalam PSAK baru, amortisasi atau kerugian aktuaria serta dampak perubahan kurtailmen dan penyelesaian dihapuskan. Perhitungan aktuaris di atas telah sesuai dengan perhitungan yang diatur dalam PSAK no 24 revisi 2013.

\section{Dampak penerapan PSAK 24 revisi 2013 pada Laporan Keuangan Perusahaan PT XYZ 2015 untuk periode 2013}

Dampak dari adanya penerapan PSAK 24 revisi 2013 terhadap Laporan Keuangan perusahaan dapat dilihat pada adanya penyajian kembali pada beban imbalan pascakerja untuk periode 2013 pada Laporan Laba Rugi periode 31 Desember 2013 perusahaan ABC, dapat dilihat pada Tabel 5 berikut ini.

Berdasarkan laporan laba rugi di atas, beban imbalan pascakerja yang menerapkan PSAK revisi mengalami penurunan yakni dari Rp 31.281.016.069 menjadi Rp 11.320.581.867, hal ini dikarenakan perhitungan beban imbalan pasca kerja periode berjalan tidak mengakui lagi amortisasi akumulasi (keuntungan) kerugian aktuarial sebesar Rp 19.960.434.202.

Dampak lainnya dari adanya penerapan PSAK 24 revisi 2013 terhadap Laporan Keuangan perusahaan dapat dilihat pada adanya penyajian kembali pada liabilitas (kewajiban) imbalan pascakerja untuk periode 2013 pada Laporan Posisi Keuangan per 31 Desember 2013 perusahaan ABC, dapat dilihat pada Tabel 6 berikut ini. 
Tabel 5. Beban Imbalan Pasca kerja pada Laporan Laba Rugi periode 31 Desember 2013

\begin{tabular}{lrr}
\hline $\begin{array}{l}\text { Beban imbalan pasca kerja (Laporan Laba Rugi) } \\
\text { (dalam Rupiah) }\end{array}$ & 2013 & \multicolumn{1}{c}{$\begin{array}{c}2013 \\
\text { (Restated) }\end{array}$} \\
\hline Beban Jasa Kini & & 5.467 .094 .719 \\
Beban bunga & 5.853 .487 .148 & 5.853 .487 .719 \\
Amortisasi akumulasi (keuntungan) kerugian aktuarial & 19.960 .434 .202 & - \\
\hline Jumlah beban imbalan pascakerja & 31.281 .016 .069 & 11.320 .581 .867 \\
\hline
\end{tabular}

Sumber: Perusahaan XYZ

Tabel 6. Liabilitas Imbalan Pascakerja pada Laporan Posisi Keuangan per 31 Desember 2013

\begin{tabular}{lrr}
\hline $\begin{array}{l}\text { Liabilitas imbalan pascakerja (Laporan Posisi Keuangan) } \\
\text { (dalam Rupiah) }\end{array}$ & 2013 & \multicolumn{1}{c}{$\begin{array}{c}2013 \\
\text { (Restated) }\end{array}$} \\
\hline Saldo awal tahun, 1 Jan & 18.614 .003 .072 & 18.614 .003 .072 \\
Beban imbalan pascakerja periode berjalan & 31.281 .016 .069 & 11.320 .581 .867 \\
Realisasi imbalan pascakerja periode berjalan & $(28.449 .960 .866)$ & $(28.449 .960 .866)$ \\
Pendapatan komprehensif lainnya & - & $(62.855 .644 .766)$ \\
\hline Jumlah liabilitas imbalan pascakerja per 31 Des & 21.445 .058 .275 & 64.340 .268 .839 \\
\hline Sumber: Perusahaan XYZ & &
\end{tabular}

Berdasarkan laporan posisi keuangan per 31 Desember 2013 di atas, liabilitas imbalan pascakerja yang menerapkan PSAK revisi mengalami kenaikan yang signifikan yakni dari $\mathrm{Rp}$ 21.445.058.275 menjadi $\mathrm{Rp}$ 64.340.268.839, hal ini dikarenakan perhitungan liabilitas imbalan pascakerja periode berjalan mengakui adanya pendapatan komprehensif lainnya sebesar Rp 62.855.644.766. PSAK revisi tidak mengakui lagi amortisasi akumulasi (keuntungan) kerugian aktuarial, namun keuntungan dan kerugian aktuarial ini langsung diakui dalam pendapatan komprehensif lain.

\section{PENUTUP}

Terdapat perbedaan antara antara PSAK 24 revisi 2010 dan 2013, yang sangat signifikan yakni pengakuan keuntungan/kerugian actuarial, komponen dari beban imbalan pascakerja, dan komponen dari liabilitas (kewajiban) imbalan pascakerja. Penerapan PSAK revisi 2013 berdampak perlu dilakukannya penilaian kembali perhitungan beban imbalan pascakerja dan liabilitas (kewajiban) imbalan pascakerja oleh pihak aktuaris independen. Penerapan ini menyebabkan dilakukan penyajian kembali saldo beban imbalan pascakerja dan liabilitas (kewajiban) imbalan pascakerja. Saldo beban imbalan pascakerja menjadi lebih kecil sedangkan liabilitas (kewajiban) imbalan pasca kerja mengalami kenaikan yang signifikan. 


\section{DAFTAR PUSTAKA}

Alali, F.A., \& Foote, P.S. 2012. The Value Relevance Of International Financial Reporting Standards: Empirical Evidence in an Emerging Market. The International Journal of Accounting, 47, 85-108.

Cahyonowati, N., Ratmon, D. 2012. Adopsi IFRS dan Relevansi Nilai Informasi Akuntansi. Jurnal Akuntansi dan Keuangan, 14 (2), 105-115

Ikatan Akuntan Indonesia. 2014. Pernyataan Standar Akuntansi Keuangan (PSAK 24) Revisi 2013 Tentang Imbalan Kerja.

Ikatan Akuntan Indonesia. 2014. Pernyataan Standar Akuntansi Keuangan (PSAK 1) Revisi 2013 Tentang Penyajian Laporan Keuangan.
Ikatan Akuntan Indonesia. 2010. Pernyataan Standar Akuntansi Keuangan (PSAK 24) Revisi 2010 Tentang Imbalan Kerja.

Paath, Amelia, C.,A., Grace, B. Nangoi, 2015. Evaluasi Penerapan PSAK 24 Revisi 2010 Mengenai Imbalan Kerja Khususnya Imbalan Setelah Bekerja Pada Bank Sulut. Jurnal EMBA 3, (1), 35-42

Tjandra, G. 2014. Dampak Penerapan PSAK 24 (revisi 2010), FAS 158 dan ED PSAK 24 revisi 2013 Imbalan Paska kerja Program Imbalan Pasti. Media Bisnis. 6,(1), 16-21.

Undang-Undang Republik Indonesia Nomor 13 Tahun 2003 tentang Ketenagakerjaan.http://accounting/ binus.ac.id/2014/09/02/7022/ 